\title{
RHEUMATOID ARTHRITIS OF THE CERVICAL SPINE
}

\section{AN ANALYSIS OF 333 CASES}

BY

\author{
P. W. CONLON, I. C. ISDALE, AND B. S. ROSE \\ From the Queen Elizabeth Hospital, Rotorua, New Zealand
}

A retrospective survey of 845 patients with rheumatoid arthritis seen at the Queen Elizabeth Hospital, Rotorua, showed that approximately 60 per cent. had signs or symptoms of neck involvement, which varied from mild to severe (Conlon, Isdale, and Rose, 1963). Seven patients had radiological evidence of moderate or severe atlantoaxial subluxation, but it was felt that subluxation was probably more common than these figures indicated, particularly as other surveys by Martel (1961), Bland, Davis, London, van Buskirk, and Duarte (1963), and Serre, Simon, Janicot, and Lévy (1964), using tomography, showed a much higher incidence of atlanto-axial subluxation where this was specifically sought. For this reason a prospective study was planned to ascertain the frequency of this abnormality and other rheumatoid changes, the significance of the degenerative changes seen in these $x$ rays, and the frequency with which neurological signs resulted from rheumatoid changes, particularly cervical subluxation.

\section{Material and Methods}

In the 12 months starting in October, 1962, 848 patients were admitted to the Queen Elizabeth Hospital, Rotorua. At the time of admission, in addition to routine $x$ rays of chest, hands, and feet, a lateral view of the cervical spine in maximum flexion, taken at 6 feet and centred on C2 was obtained. These radiographs were subsequently read independently by two observers, with particular regard to the presence or absence of features previously suggested as common in or characteristic of rheumatoid disease (Bland and others, 1963) and degenerative change. When the two observers disagreed, the films were reassessed and referred to a further independent observer. The patients were assessed by the American Rheumatism Association criteria for the diagnosis of rheumatoid arthritis. Cases were assigned to the degenerative joint disease group regardless of the site and cause of osteo- -7 arthritic change; thus this group included cases of $N$ generalized osteo-arthritis (Kellgren and Moore, 1952), 응 malum coxae senilis, post-traumatic osteo-arthritis, $\underset{ }{\triangle}$ congenital abnormalities with secondary degenerative $\vec{z}$ change, and other secondary degenerative conditions. There was a miscellaneous group of 190 cases of other $\bar{\rho}$ arthropathies and non-rheumatic conditions.

Correlation was subsequently attempted between the $\vec{\theta}$ clinical and radiological findings, with particular regage o to the presence or absence of various rheumatota criteria and $x$ ray change.

Tomography was not employed, though at times would have been of great use, and this may have led to some under-emphasis of certain changes, particularly erosion of the odontoid peg and mild degrees of platysba- $\stackrel{\mathbb{Q}}{\triangle}$ sia.

The usual criterion for atlanto-axial subluxation (Martel, 1961) is an increase in the radiological separation of the odontoid peg and the ventral part of the atlas to greater than $2.5 \mathrm{~mm}$. in females and $3.0 \mathrm{~mm}$. in males. In a number of examples the definition of the two bones was poor, or the separation was greater in the upper as compared with the lower part of the adjacent aspects of these two bones; in doubtful cases subluxation was held not to be present.

Definition of apophyseal joint changes also presented difficulties, and these were not recorded as eroded or 9 blurred where doubt existed.

Particular regard was paid to the presence or absence $\frac{T}{O}$ of osteophytes accompanying loss of disk space (Sharp, Purser, and Lawrence, 1958), but frequently osteophytes $N$ were not found at one level, though obviously present at another in the same $x$ ray.

Peripheral hand and foot $x$ ray changes were classified $\omega$ in five grades: normal; osteoporosis only; small multiple 웅 erosions; large multiple erosions; and gross widespread 0 destructive changes of "mutilans" type.

For the purpose of analysis, the latex test results were $\mathscr{\bigotimes}$ similarly grouped into 1 in $\mathbf{4 0}$ or under (= normal); 1 in 40 or 1 in 80; 1 in 160 or 1 in 320; and above this. 


\section{Results}

Of 848 patients, 333 (103 male and 230 female) had rheumatoid arthritis (classical 233; definite 85; probable 15), and 325 (135 male and 190 female) were placed in the degenerative joint disease category (Table I).

Of the 325 osteo-arthritic patients, 173 had symptoms referable to the neck, but 296 (91 per cent.) had $x$-ray evidence of degenerative change, the incidence of such change being related to age (Table II).

Of 333 patients in the rheumatoid group, 295 (88 per cent.) had symptoms referable to the neck, and 211 showed changes which were thought to be typical of degenerative arthritis with loss of disk space, osteophytes at the same level, or apophyseal degenerative change. Changes categorized as due to the rheumatoid arthritis were seen in 167 patients ( 50 per cent.); fifty showed no abnormality on $x$ ray, but there was no relation between the absence of radiological change and the absence of symptoms. Of 38 with no symptoms, only sixteen had normal $x$ rays. The degenerative changes are classified by age in Table III (overleaf).

\section{Analysis of Rheumatoid Changes}

The incidence of certain rheumatoid abnormalities are shown in Table IV (overleaf), the most frequent being changes in the apophyseal joints, most often between the second and third vertebrae. These at times were definitely eroded, and on other occasions showed a local osteoporosis and blurring. Osteoporosis was seen in 69 patients and was frequently localized to a segment of the spine, usually in the upper spine. End-plate erosion was seen in 48 patients and was frequently multiple.

The most striking abnormality was the presence of subluxation (Fig. 1, overleaf). This most frequently occurred between the atlas and axis and separation of more than $2.5 \mathrm{~mm}$. in females and $3 \mathrm{~mm}$. in males was found in no less than 84 ( 25 per cent.) of the whole series.

TABLE 1

CERVICAL SPINE ABNORMALITY IN 848 PATIENTS

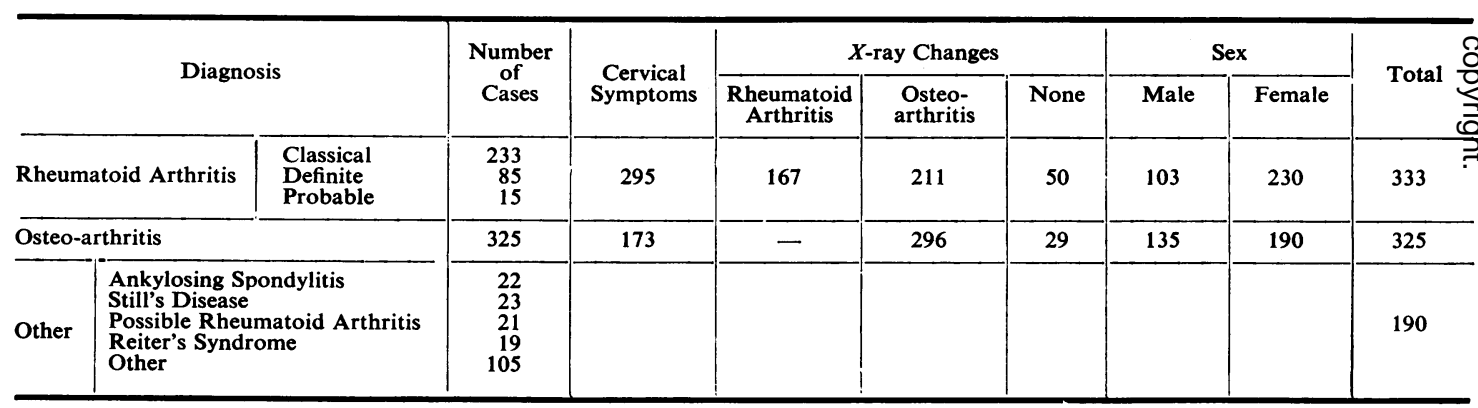

TABLE II

DEGENERATIVE CHANGE RELATED TO AGE

\begin{tabular}{|c|c|c|c|c|c|c|c|c|c|c|c|c|c|}
\hline \multirow{2}{*}{$\begin{array}{l}\text { Diagnosis } \\
\text { Age (yrs) }\end{array}$} & \multirow{2}{*}{$\begin{array}{l}\cdots \\
\cdots \\
\end{array}$} & \multirow{2}{*}{$\cdots$} & \multirow{2}{*}{ 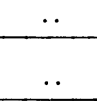 } & \multicolumn{5}{|c|}{ Osteo-arthritis } & \multicolumn{5}{|c|}{ Rheumatoid Arthritis } \\
\hline & & & & $\begin{array}{l}39 \text { and } \\
\text { Under }\end{array}$ & $\begin{array}{c}40 \text { to } \\
49\end{array}$ & $\begin{array}{r}50 \text { to } \\
59\end{array}$ & $\begin{array}{l}60 \text { and } \\
\text { Over }\end{array}$ & Total & $\begin{array}{l}39 \text { and } \\
\text { Under }\end{array}$ & $\begin{array}{r}40 \text { to } \\
49\end{array}$ & $\begin{array}{r}50 \text { to } \\
59\end{array}$ & $\begin{array}{l}60 \text { and } \\
\text { Over }\end{array}$ & Total \\
\hline Total Cases .. & $\cdots$ & $\cdots$ & $\cdots$ & 14 & 29 & 83 & 199 & 325 & 40 & 65 & 109 & 119 & 333 \\
\hline $\begin{array}{c}\text { With Degenerative } \\
\text { Joint Disease }\end{array}$ & e & $\cdots$ & $\cdots$ & 6 & 11 & 5 & 7 & 29 & 34 & 41 & 31 & 17 & 122 \\
\hline Not Affected & $\cdots$ & 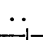 & $\cdots$ & 8 & 18 & 78 & 192 & 296 & 6 & 24 & 79 & 102 & 211 \\
\hline \multirow{2}{*}{$\begin{array}{l}\text { Degenerative } \\
\text { Joint Disease }\end{array}$} & Level & & $\begin{array}{l}\text { Intervertebral } \\
\text { Apophyseal }\end{array}$ & $\begin{array}{r}15 \\
4\end{array}$ & $\begin{array}{l}40 \\
11\end{array}$ & $\begin{array}{r}169 \\
43\end{array}$ & $\begin{array}{l}538 \\
243\end{array}$ & & $\begin{array}{l}4 \\
4\end{array}$ & $\begin{array}{l}41 \\
11\end{array}$ & $\begin{array}{r}144 \\
20\end{array}$ & $\begin{array}{r}198 \\
65\end{array}$ & \\
\hline & $\begin{array}{c}\text { Mean } \\
\text { No. }\end{array}$ & & $\begin{array}{l}\text { Intervertebral } \\
\text { Apophyseal }\end{array}$ & $\begin{array}{l}\mathbf{1} \cdot \mathbf{1} \\
\mathbf{0} \cdot \mathbf{3}\end{array}$ & $\begin{array}{l}2 \cdot 1 \\
0 \cdot 6\end{array}$ & $\begin{array}{l}2 \cdot 2 \\
0 \cdot 55\end{array}$ & $\begin{array}{l}2 \cdot 7 \\
1 \cdot 25\end{array}$ & & $\begin{array}{l}0 \cdot 1 \\
0 \cdot 1\end{array}$ & $\begin{array}{l}1 \cdot 3 \\
0 \cdot 2\end{array}$ & $\begin{array}{l}1 \cdot 4 \\
0 \cdot 2\end{array}$ & $\begin{array}{l}1 \cdot 8 \\
0 \cdot 6\end{array}$ & \\
\hline \multicolumn{4}{|l|}{ Osteoporosis } & 一 & - & - & 44 & $\begin{array}{c}44 \\
\text { (14 per } \\
\text { cent.) }\end{array}$ & 1 & 4 & 21 & 43 & $\begin{array}{c}69 \\
\text { (21 per } \\
\text { cent.) }\end{array}$ \\
\hline
\end{tabular}


DEGENERATIVE CHANGES AT INTERVERTEBRAL AND APOPHYSEAL JOINTS, BY AGE

\begin{tabular}{|c|c|c|c|c|c|c|c|c|c|}
\hline \multirow{2}{*}{$\frac{\text { Diagnosis }}{\text { Age (yrs) }}$} & \multirow{2}{*}{$\cdots$} & \multirow[b]{2}{*}{ Under 50} & \multicolumn{2}{|c|}{ Osteo-arthritis } & \multirow[b]{2}{*}{ Total } & \multirow[b]{2}{*}{ Under 50} & \multicolumn{2}{|c|}{ Rheumatoid Arthritis } & \multirow[b]{2}{*}{ Total } \\
\hline & & & 50 to 59 & Over 59 & & & 50 to 59 & Over 59 & \\
\hline Total Patients . . & $\cdots$ & 43 & 83 & 199 & 325 & 105 & 109 & 119 & 333 \\
\hline \multicolumn{2}{|c|}{$\begin{array}{l}\text { With Osteo-arthritic Changes } \\
\text { Not Affected }\end{array}$} & $\begin{array}{l}26 \\
17\end{array}$ & $\begin{array}{r}78 \\
5\end{array}$ & $\begin{array}{r}192 \\
7\end{array}$ & $\begin{array}{r}296 \\
39\end{array}$ & $\begin{array}{l}30 \\
75\end{array}$ & $\begin{array}{l}79 \\
30\end{array}$ & $\begin{array}{r}102 \\
17\end{array}$ & $\begin{array}{l}211 \\
122\end{array}$ \\
\hline $\begin{array}{l}\text { Intervertebral Degen- } \\
\text { erative Changes } \\
\text { excluding “disk } \\
\text { narrowing with no } \\
\text { osteophytosis" }\end{array}$ & $\begin{array}{l}1 / 2 \\
2 / 3 \\
3 / 4 \\
4 / 5 \\
5 / 6 \\
6 / 7\end{array}$ & $\begin{array}{r}\frac{1}{8} \\
12 \\
20 \\
14\end{array}$ & $\begin{array}{r}2 \\
8 \\
18 \\
29 \\
66 \\
46\end{array}$ & $\begin{array}{r}2 \\
30 \\
81 \\
108 \\
169 \\
148\end{array}$ & $\begin{array}{r}5 \\
38 \\
107 \\
149 \\
245 \\
208\end{array}$ & $\begin{array}{r}- \\
1 \\
5 \\
6 \\
19 \\
14\end{array}$ & $\begin{array}{r}1 \\
2 \\
19 \\
17 \\
56 \\
49\end{array}$ & $\begin{array}{r}1 \\
8 \\
22 \\
33 \\
83 \\
71\end{array}$ & $\begin{array}{r}2 \\
11 \\
46 \\
56 \\
158 \\
134\end{array}$ \\
\hline $\begin{array}{l}\text { Apophyseal Degen- } \\
\text { erative Changes }\end{array}$ & $\begin{array}{l}2 / 3 \\
3 / 4 \\
4 / 5 \\
5 / 6 \\
6 / 7\end{array}$ & $\begin{array}{r}11 \\
1 \\
\frac{1}{1}\end{array}$ & $\begin{array}{r}27 \\
4 \\
3 \\
5 \\
4\end{array}$ & $\begin{array}{r}111 \\
58 \\
34 \\
24 \\
16\end{array}$ & $\begin{array}{r}149 \\
63 \\
37 \\
31 \\
21\end{array}$ & $\begin{array}{r}4 \\
5 \\
3 \\
3 \\
-\end{array}$ & $\begin{array}{r}12 \\
5 \\
1 \\
2\end{array}$ & $\begin{array}{r}20 \\
15 \\
16 \\
10 \\
4\end{array}$ & $\begin{array}{r}36 \\
25 \\
20 \\
13 \\
6\end{array}$ \\
\hline $\begin{array}{l}\text { Subluxation (minor) } \\
\text { related to Degene- } \\
\text { rative Joint Disease }\end{array}$ & $\begin{array}{l}2 / 3 \\
3 / 4 \\
4 / 5 \\
5 / 6 \\
6 / 7\end{array}$ & $\begin{array}{r}- \\
-3 \\
1 \\
-\end{array}$ & $\begin{array}{l}3 \\
6 \\
3 \\
5 \\
1\end{array}$ & $\begin{array}{r}21 \\
37 \\
28 \\
6 \\
2\end{array}$ & $\begin{array}{r}24 \\
43 \\
34 \\
12 \\
3\end{array}$ & & & & \\
\hline
\end{tabular}

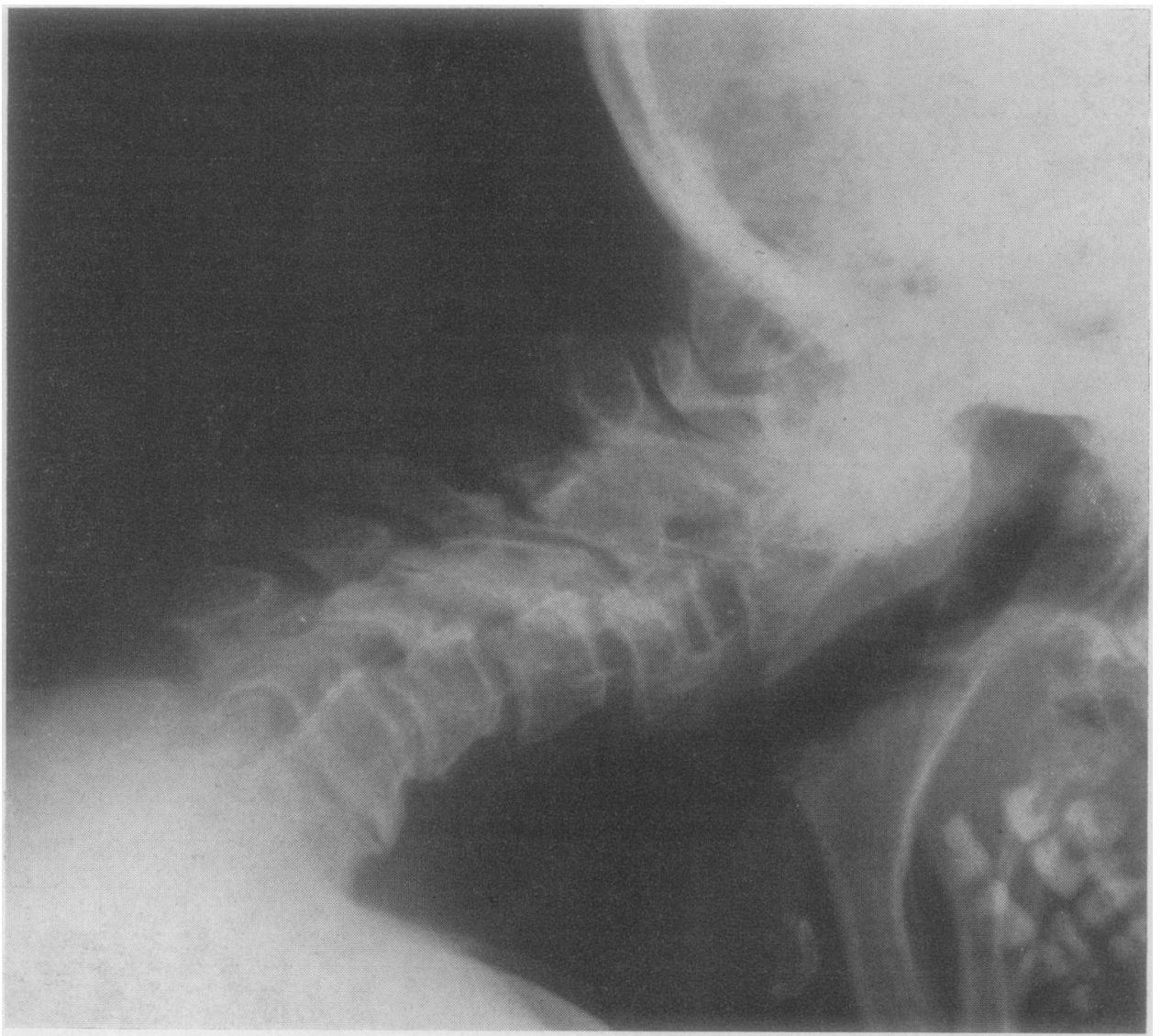

Fig. 1.-A case of classical rheumatoid arthritis, showing cervical subluxation, end plate erosions, and apophyseal joint erosion 
TABLE IV

RHEUMATOID FEATURES OF CERVICAL SPINE $X$ RAYS

\begin{tabular}{|c|c|c|c|c|c|c|c|}
\hline Group & $\ldots$ & . & . & $\cdots$ & Queen Elizabeth Hospital & Martel (1961) & Serre and Others (1964) \\
\hline No. of Cases & $\cdots$ & $\cdots$ & . & $\cdots$ & 333 & 34 & 60 \\
\hline \multicolumn{5}{|c|}{ X-ray Technique and View } & Lateral Flexion & $\begin{array}{l}\text { Lateral Flexion/Extension } \\
\text { Tomograms }\end{array}$ & Tomograms \\
\hline \multicolumn{5}{|c|}{$\begin{array}{l}\text { Symptoms } \\
\text { Atlanto-axial Subluxation } \\
\text { Serial Subluxation } \\
\text { Osteoporosis } \\
\text { Odontoid Erosion } \\
\text { Platysbasia } \\
\text { Erosion Vertebral End-plates } \\
\text { Erosion Spinus Processes } \\
\text { Ankylosis } \\
\text { Apophyseal Joint Erosion or Blurring } \\
\text { Disk Narrowing without Osteophytosis } \\
\text { Normal X-ray }\end{array}$} & $\begin{array}{r}295 \\
84 \text { (25 per cent. }) \\
23 \\
69 \\
8 \\
1 \\
48 \\
8 \\
4 \\
106 \\
59 \\
50\end{array}$ & $\begin{array}{r}34 \\
24 \\
5 \\
* \\
12 \\
10 \\
4 \\
8 \\
7 \\
* \\
* \\
*\end{array}$ & $\begin{array}{l}41 \\
23 \text { (38 per cent.) } \\
4 \\
* \\
41 \\
13 \\
* \\
* \\
* \\
* \\
*\end{array}$ \\
\hline
\end{tabular}

* Not stated.

Serial subluxation of the upper cervical vertebrae was found much less frequently but was at times marked.

In the osteo-arthritic patients subluxation of this degree was not seen, though minor changes were common (Table III), and there were no examples of atlanto-axial subluxation. The infrequent examples or of serial subluxation in osteo-arthritics were always ? very slight, involving no more than two segments, $\vec{O}$ and usually immediately above, or less commonly 을 below or between, areas of marked degenerative change (Fig. 2).

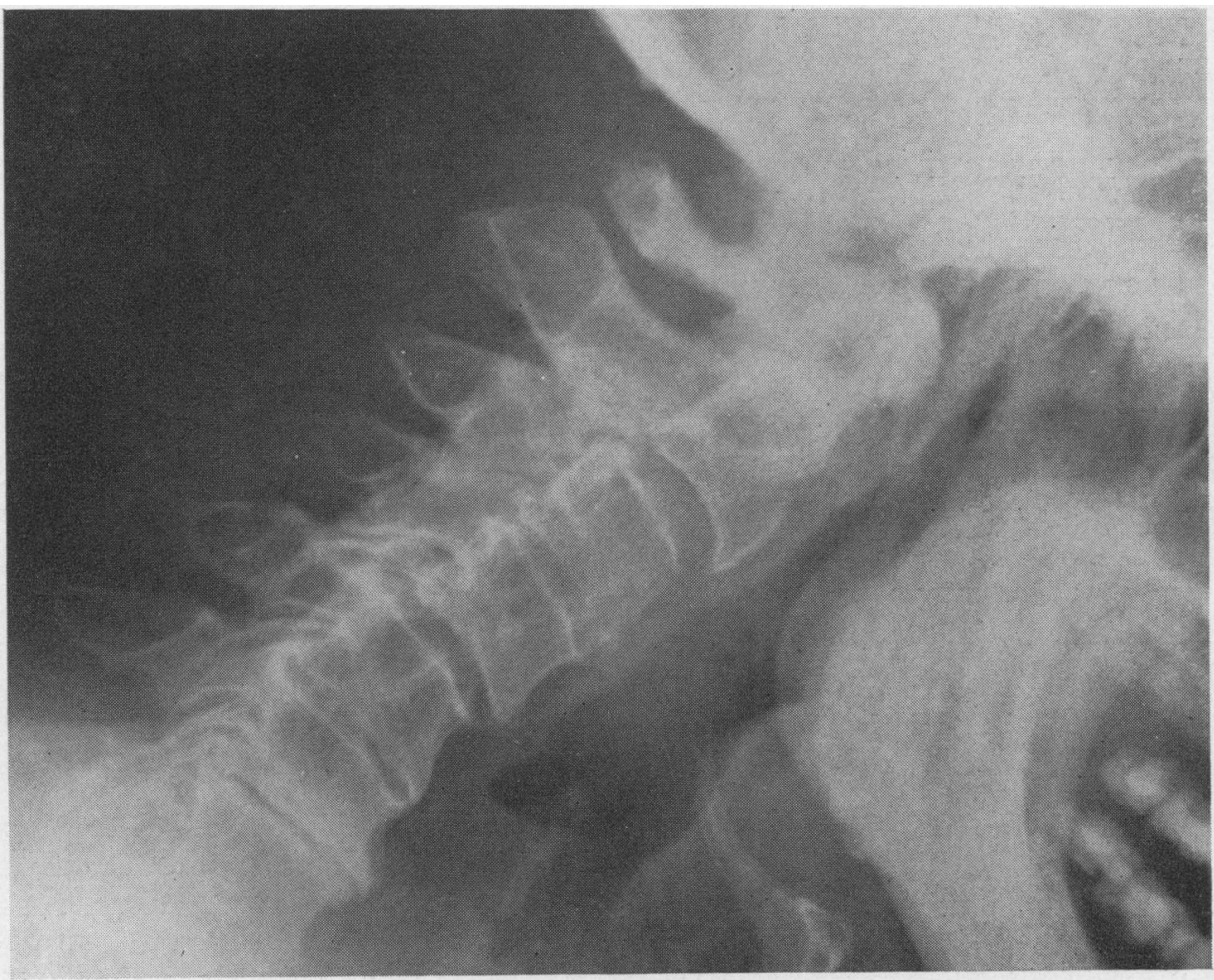

Fig. 2.-A case of generalized osteo-arthritis, showing intervertebral disk changes, minor subluxation, and osteophytosis. 
The clinical data of patients showing atlantoaxial subluxation (A.A.S.) were analysed (Table V), and this most characteristic of the rheumatoid findings cited by Martel, was found to be statistically related to joint instability (of knees, wrists, and elsewhere); subcutaneous nodules; positive latexagglutination test; and severity of peripheral $x$ ray changes. No significant relationship was demonstrated with sex, oral corticosteroid therapy, dura- tion of disease, or classification of rheumatoid $]$ arthritis as classical, definite, or probable. Particularly striking was the relationship between A.A.S. and marked joint destruction, whether patchy or generalized as "arthritis mutilans".

\section{Neurological Changes (Table VI).}

There were no cases of disabling neurological abnormality. Upper motor neurone signs and

TABLE V

ATLANTO-AXIAL SUBLUXATION IN RHEUMATOID SUBJECTS RELATED TO OTHER DATA

\begin{tabular}{|c|c|c|c|c|c|}
\hline Subluxation. . & $\cdots$ & Present & Absent & Total & $\chi_{2}$ and Probability \\
\hline Joint Instability & & 50 & 94 & 144 & $\chi 2=12 \cdot 13 ; n=1 ; \mathrm{P}<0 \cdot 0005$ \\
\hline Subcutaneous Nodules & & 34 & 67 & 101 & $\chi^{2}=5.47 ; n=1 ; \mathrm{P}<0.02$ \\
\hline \multirow{5}{*}{ Latex Test } & Under $1 / 40$ & 19 & 70 & 89 & \multirow{5}{*}{$\not 2=12 \cdot 78 ; n=4 ; P<0 \cdot 02$} \\
\hline & $1 / 40,1 / 80$ & 8 & 35 & 43 & \\
\hline & $1 / 160 / 320$ & 19 & 64 & 83 & \\
\hline & 6401280 & 14 & 41 & 55 & \\
\hline & Over $1 / 1280$ & 24 & 39 & 63 & \\
\hline \multicolumn{2}{|c|}{ Hand and Foot $X$ ray no Change } & 9 & 69 & 78 & \multirow{5}{*}{$\chi 2=20 \cdot 58 ; n=4 ; P<0 \cdot 0005$} \\
\hline \multicolumn{2}{|c|}{ Osteoporosis Dubious Erosions } & 9 & 52 & 61 & \\
\hline \multicolumn{2}{|c|}{ Small Multiple Erosions ++} & 28 & 63 & 91 & \\
\hline \multicolumn{2}{|l|}{ Large Multiple Erosions } & 16 & 31 & 47 & \\
\hline \multicolumn{2}{|c|}{ Widespread Destructive Changes (Mutilans) } & 22 & 34 & 56 & \\
\hline \multicolumn{2}{|l|}{ Female Sex } & 57 & 173 & 230 & $\chi^{2}=0.078 ; n=1 ; \mathrm{P}: \mathrm{n} . \mathrm{s}$ \\
\hline \multicolumn{2}{|l|}{ Oral Corticosteroids } & 16 & 43 & 59 & $\chi 2=0 \cdot 136 ; n=1 ; P:$ n.s. \\
\hline \multirow{3}{*}{ A.R.A. Classification } & Classical & 62 & 171 & 233 & \multirow{3}{*}{$\chi 2=0.994 ; n=2 ;$ P: n.s. } \\
\hline & Definite & 18 & 69 & 85 & \\
\hline & Probable & 4 & 11 & 15 & \\
\hline \multirow{3}{*}{ Duration (yrs) } & $<5$ & 25 & 105 & 130 & \multirow{3}{*}{$\chi^{2}=4 \cdot 618 ; n=2 ; \mathrm{P}:$ n.s. } \\
\hline & $5-9$ & 19 & 54 & 73 & \\
\hline & $10 \div$ & 40 & 90 & 130 & \\
\hline \multicolumn{2}{|l|}{ Total } & 84 & 249 & 333 & \\
\hline
\end{tabular}

TABLE VI

NEUROLOGICAL ABNORMALITY IN RHEUMATOID ARTHRITIS AND OSTEO-ARTHRITIS, BY AGE, AND DURATION OF DISEASE (YRS)

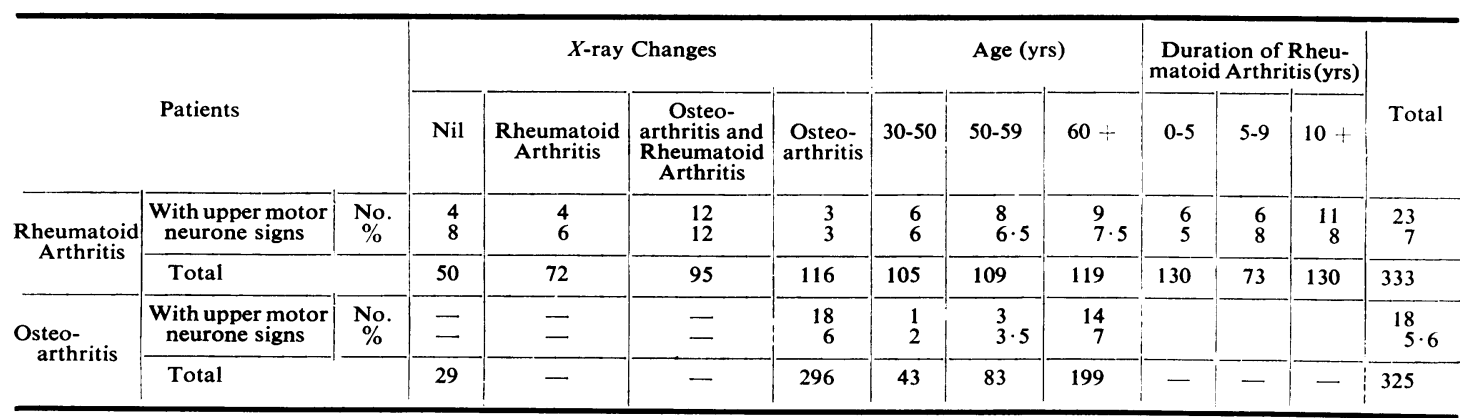


diminished vibration sense in the lower $1 \mathrm{mbs}$ were found in 23 cases of rheumatoid arthritis, of whom four showed no radiological abnormality. Of these 23 cases, eleven showed A.A.S., including four in which this was the only radiological sign. The presence of neurological changes was not related to age or duration of rheumatoid arthritis.

Upper motor neurone signs were less frequent among the osteo-arthritic cases (Table VI), but of the 105 patients over the age of 69 , eleven $(10.5$ per cent.) were affected.

\section{Disk Changes}

Intervertebral disk changes with osteophytes were found in the great majority of the osteo-arthritic group. With the rise in age not only did a higher percentage of patients show these radiological changes but the number of levels involved in each patient also rose. Apophyseal joint involvement of a degenerative type was also more frequent with increasing age (Table II).

In the rheumatoid patients the incidence of degenerative changes of this type was considerably lower and less closely related to age.

Contrary to the findings of Sharp, Purser and Lawrence (1958), the level of intervertebral degenerative changes of the two groups of patients was comparable (Table III), the C5-6 articulation being the most frequently involved, while apophyseal changes were seen most commonly in the C2-3, C3-4 lateral joints.

Disk narrowing without osteophytes was very uncommon on the osteo-arthritic patients, but was seen in 59 rheumatoid patients, in fifteen of them at multiple levels (Table VII).

TABle VII

333 RHEUMATOID PATIENTS SHOWING DISK NARROWING WITHOUT OSTEOPHYTOSIS, BY AGE

\begin{tabular}{l|c|c|c|c}
\hline \multirow{2}{*}{ Level } & \multicolumn{4}{|c}{ Age (yrs) } \\
\cline { 2 - 5 } & Under 50 & 50 to 59 & Over 59 & Total \\
\hline C $2 / 3$ & 1 & 2 & 6 & 9 \\
C $3 / 4$ & 2 & 17 & 13 & 22 \\
C $4 / 5$ & 1 & 1 & 15 & 17 \\
C $5 / 6$ & - & 8 & 16 & 24 \\
C $6 / 7$ & - & 2 & 4 & 6 \\
\hline
\end{tabular}

End-plate erosion was seen in 48 rheumatoid patients and in a small number of osteo-arthritics, where these changes, usually at the lower levels, were associated with marked loss of disc space and considerable osteophytosis.

As expected, osteoporosis was much more marked in the rheumatoid patients, being evident in 21 per cent. of the whole group in persons of all ages. In the osteo-arthritic group osteoporosis was seen only in persons above the age of 60 (Table II).

\section{Discussion}

Of the radiological features suggested as characteristic of cervical involvement in rheumatoid arthritis (Bland and others, 1963; Sharp and others, 1958), vertebral subluxation proved to be the most characteristic and was the most easily recognized. Correlation with those cases of rheumatoid arthritis showing joint laxity and widespread peripheral destructive lesions was striking, but no correlation was found with the exhibition of oral corticosteroids or duration of disease. In contrast to the osteoarthritic group, where minor subluxations are related to mechanical limitation of movement, rheumatoid subluxation appears to follow the bone and ligamentous destruction due to active inflammatory disease. Our technique of taking lateral radiographs in flexion may have led to an underestimation as compared with studies employing tomography. Our cases were an inclusive group admitted to hospital for active physiotherapy and rehabilitation without bias towards cases showing neurological changes or unusual severity of symptoms of disease activity, and thus may more closely reflect the incidence of neck involvement in rheumatoid arthritis than some earlier studies such as those of Serre and others (1964) and Martel (1961).

While minor subluxations were common in the osteo-arthritic group, serial subluxations and atlantoaxial subluxations were found only in the rheumatoid group. Disk narrowing without accompanying osteophytic changes was seen very infrequently in the osteo-arthritic group but was a relatively common feature of the rheumatoid group. Sharp and others (1958) placed reliance on the narrowing of multiple disk spaces, particularly those between $\mathrm{C} 2 / 3$ and $3 / 4$, but in this series the incidence of disk narrowing, usually accompanied by osteophytic change, was higher in the osteo-arthritic than in the rheumatoid patients, even excluding those over 60 years of age. End-plate erosion was uncommon except in the rheumatoid patients, and erosion of the spinous processes was seen only in eight rheumatoid patients. Congenital abnormality of the neck was equally common in the two groups, and most usually took the form of a hemi-vertebrae (seen on five occasions). Neurological abnormalities were uncommon in both groups, and contrary to expectation did not appear to be closely related to the presence of subluxation. In the osteoarthritic group the incidence of such signs increases 
with age, and 10.5 per cent. of the 105 such patients over the age of 69 showed this abnormality, a figure which compares closely with that of Pallis, Jones, and Spillane (1954) working with a similar age group.

The presence of subluxation did not pose any problems of managment and several of these patients have undergone surgery without difficulty in anaesthesia. We have attempted mobilization of the neck of all patients before operation, and during anaesthesia great care is taken not to flex or extend the neck acutely, particularly during intubation (Isdale, Ridings, and Tapsell, 1964).

As the radiological abnormalities discussed above may occur early in the course of rheumatoid arthritis, such changes may assist in the definite diagnosis of this condition.

\section{Summary}

A prospective radiological study of cervical changes in 333 patients with probable, definite, or classical rheumatoid arthritis is reported. Degenerative changes comparable to those seen in the control group of 325 patients with degenerative joint disease were common. Radiological features characteristic of the rheumatoid group were atlantoaxial subluxation, serial subluxation, and disk narrowing without osteophytosis. No great reliance could be placed on the level of disk change when osteophytosis was present.

Cervical subluxation was closely related to peripheral destructive changes and joint instability, and to a less degree with the presence of subcutaneous nodules and a positive of latex test.

We wish to thank the Director General of Health, Dr. D. P. Kennedy, for permission to publish this paper.

\section{REFERENCES}

Bland, J. H., Davis, P. H., London, M. G., van Buskirk, F. W., and Duarte, C. G. (1963). Arch. intern. Med., 112, 892.
Conlon, P. W., Isdale, I. C., and Rose, B. S. (1963嫼 N.Z. med.J., 62, 279.

Isdale, I. C., Ridings, K. W., and Tapsell, P. W. (1966 Ibid., 63, 140.

Kellgren, J. H., and Moore, R. (1952). Brit. med. J., 点. 181.

Martel, W. (1961). Amer. J. Roentgenol., 86, 223.

Pallis, C., Jones, A. M., and Spillane, J. D. (1954 Brain, 77, 274.

Serre, H., Simon, L., Janicot, J. Y., and Lévy, F. (1964웧 Presse méd., 72, 213.

Sharp, J., Purser, D. W., and Lawrence, J. S. (1958. Ann. rheum. Dis., 17, 303.

L'arthrite rhumatismale de l'épine cervicale. Analyse $\vec{\circ}$ de 333 cas

RÉSUMÉ

On rapporte sur les résultats d'une étude radiologiquę prospective des altérations cervicales chez 333 malade atteints d'arthrite rhumatismale probable, définie classique. Les altérations dégénératives comparables celles observées dans le groupe de $\mathbf{3 2 5}$ témoins atteints de maladie articulaire dégénérative furent communes Parmi les traits radiologiques caractéristiques du groupe rhumatismal on vit la subluxation atlo-axoide, la sulo luxation en série et un rétrécissement des disques sano ostéophytose. On ne put juger qu'avec peu de confiance le déplacement du niveau en présence de l'ostéoporose.

La subluxation cervicale fut étroitement associée au altérations destructives périphériques et à l'instabilitê articulaire et, au moindre dégré, à la présence des nodules souscutanés et de la réaction au latex positive.

Artritis reumatoide de la espina cervical. Análisis de 333 casos

SUMARIO

$8 \%$

Se relata un estudio radiológico prospectivo d* alteraciones cervicales en 333 enfermos con artrit但 reumatoide probable, definida y clásica. Alteraciones degenerativas comparables a las observadas en el grupo de 325 testigos con enfermedad articular degenerativa fueron comunes. Como rasgos radiológicos caracterís. ticos del grupo reumatoide se observaron: la subluxación atlanto-axial, la subluxación seriada y el estrechamientio discal sin osteofitosis. Se juzgaron con poca confianzầ los cambios de nivel en presencia de osteoporosis.

La subluxación cervical se vió estrechamente asociad a cambios destructivos periféricos y a la instabilida articular y, a un grado menor, con la presencia d nódulos subcutáneous y una reacción de latex positiva. 